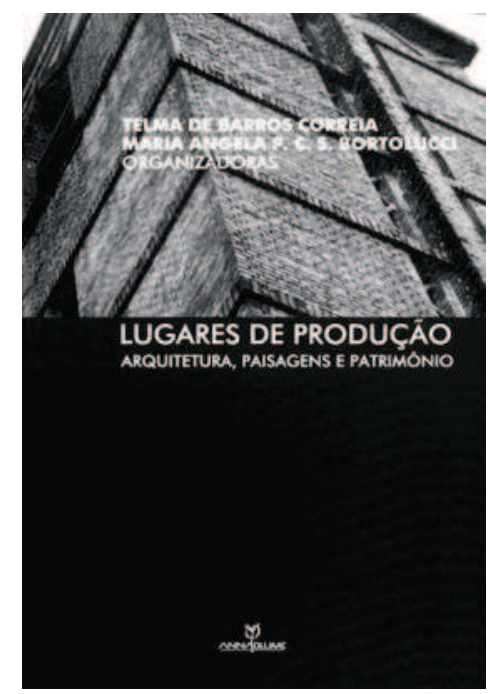

LUGARES DE PRODUÇÃO:

ARQUITETURA, PAISAGENS E PATRIMÔNIO

CORREIA, Telma de Barros; Bortolucci, Maria Angela P. C. S.

(Orgs.). São Paulo: Annablume, 2013, 244 P.

Maria Lucia Bressan Pinheiro

\title{
PAisagens CUlturais DA PRODUÇÃO E DO TRABAlho
}

Resultante do segundo de uma série de seminários voltados à problemática do patrimônio agroindustrial, iniciada em 2008, o presente livro apresenta uma preciosa coleção de textos de renomados pesquisadores do tema, que, na esteira dos desafios sempre renovados sobre a preservação do patrimônio no século 21, dialoga diretamente com novas ferramentas, instrumentos e metodologias patrimoniais, como a categoria da Paisagem Cultural, proposta pelo Comitê do Patrimônio Mundial da Unesco em 1992.

No âmbito brasileiro, a chancela da Paisagem Cultural foi criada bem mais tarde, em 2009, pela Portaria IPHAN n 127, com a seguinte definição: "A paisagem cultural é o meio natural ao qual o ser humano imprimiu as marcas de suas ações e formas de expressão, resultando em uma soma de todos os testemunhos resultantes da interação do homem com a natureza e, reciprocamente, da natureza com o homem, passíveis de leituras específicas e temporais" (Art. 2., Carta de Bagé, 2009).

É evidente, portanto, a sintonia entre tal definição e os temas dos trabalhos aqui apresentados - um dos quais traz tal referência expressa em seu próprio título: o capítulo intitulado "Uma concentração de tempos: apreendendo a paisagem cultural do rio Paraíba Açucareiro", de Juliano Loureiro de Carvalho, que, visando A valorização das relações entre o homem e meio ambiente, materializadas em assentamentos lentamente gestados sob as contingências específicas de cada ambiente natural, aborda a região tributária do Rio Paraíba em suas diversas temporalidades.

De fato, é impossível não pensar imediatamente em paisagem cultural, diante de temas tão sugestivos, como "Cultura del agua y del vino em el desierto americano: el patrimonio cultural de los oasis vitivinícolas de Mendoza y 
Califórnia", de Graciela Moretti, justamente a propositora do primeiro seminário sobre o patrimônio agroindustrial, que teve lugar em 2008, sob os auspícios da Universidade de Mendoza; ou "Configuração da fazenda cafeeira paulista ao longo da história", de Vladimir Benincasa, que trata daquela paisagem que praticamente definiu o território paulista entre meados do século 19 e inícios do 20 - e que vem desaparecendo com rapidez assustadora desde então.

Já o capítulo de Maria Aparecida de Moraes Silva, intitulado "Patrimônio negado: memórias do 'exílio' de trabalhadores rurais da fazenda Amália-SP (1966)", privilegia os aspectos imateriais de um exemplo muito específico desse tipo de paisagem cultural: a fazenda - inicialmente de café, depois de cana e outros cultivos - da família Matarazzo, com nada menos que 11 mil alqueires, distribuídos por cinco municípios. Examinando fontes documentais e orais relativas aos empregados da fazenda Amália, discute questões identitárias aí pertinentes.

Alguns dos capítulos tratam de aspectos infraestruturais que propiciaram a implantação posterior de paisagens culturais diversificadas, como é o caso do capítulo de Beatriz Mugayar Kuhl, "O legado da expansão ferroviária no interior de São Paulo e questões de preservação". Em sua abordagem do patrimônio ferroviário - ele próprio, uma paisagem cultural estruturadora de outras paisagens culturais -, analisa com propriedade o tratamento que Ihe vem sendo dispensado, no que diz respeito a sua materialidade.

O mesmo se pode dizer do texto de Mário Mendonça, sobre o uso da energia hidráulica na Bahia, que analisa a configuração espacial do abastecimento de água da cidade de Salvador; e do capítulo de Mônica Peixoto Vianna sobre o patrimônio do setor elétrico paulista - este, sim, um tema mais recente, de grande impacto em determinados pontos do território, mas ainda muito pouco estudado, apesar de sua abrangência e da rápida transformação de seus conjuntos e equipamentos.

O capítulo "Patrimônio industrial e agroindustrial: a forma e a arquitetura dos conjuntos residenciais", de Telma de Barros Correia, uma das organizadoras do livro, aborda um aspecto específico de um elemento característico das paisagens industriais, que há tempos vêm merecendo sua atenção: a das vilas operárias, abordadas aqui a partir de um olhar focado em suas características estilísticas. É possível estabelecer, assim, um interessante diálogo entre esses edifícios - exemplares da chamada "arquitetura menor", isto é, aquelas "obras modestas do passado que adquiriram um valor cultural", conforme a Carta de Veneza - e o panorama arquitetônico que Ihes é contemporâneo, aí incluídos os exemplares excepcionais.

Finalmente, Paulo César Garcez Marins faz um balanço das ações preservacionistas que vêm sendo dirigidas ao patrimônio rural paulista, não só pelos órgãos de preservação propriamente ditos, e não apenas no sentido de sua preservação física, mas também a partir do conhecimento produzido no âmbito das universidades, ou pela sociedade civil organizada em associações diversas, consubstanciado em pesquisas indispensáveis para embasar quaisquer iniciativas patrimoniais. Realiza, assim, uma utilíssima coleta de material relativo a essas múltiplas entradas, que será de grande valia a pesquisadores do tema.

Ao contrário da ênfase usualmente atribuída pelo senso comum - e, por vezes, também pelos órgãos patrimoniais - aos assentamentos humanos 
implantados em sítios naturais excepcionais ou pitorescos, os trabalhos aqui apresentados estão voltados para a reflexão e preservação de paisagens culturais vinculadas à produção e ao trabalho; encontram-se inseridas, portanto, no âmbito da habitualidade, do cotidiano - o único, segundo Ulpiano Toledo Bezerra de Menezes, capaz de efetivamente propiciar o enraizamento social e mobilizar relações de pertencimento.

As organizadoras do livro brindam-nos, portanto, com um conjunto de contribuições multidisciplinares de grande relevância, que instiga e subsidia o desenvolvimento de novos estudos de temas afins.

\section{Maria Lucia Bressan Pinheiro}

Professora do Departamento de História da Arquitetura e Estética do Projeto da FAUUSP. Tem experiência na área de Arquitetura e Urbanismo, com ênfase em História e Preservação da Arquitetura Brasileira, atuando principalmente nos seguintes temas: história da arquitetura brasileira e preservação do patrimônio cultural. Pesquisadora Associada do Núcleo de Apoio à Pesquisa Plataforma São Paulo: Cidade, Espaço, Memória (NAP-SP).

Rua do Lago, 876. Cidade Universitária 05508-080 - São Paulo, SP

(11) 3091-4555

mlbp@usp.br 